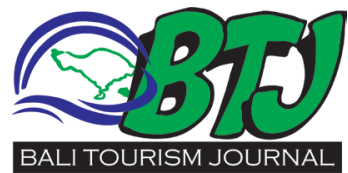

\section{Introduction of Keris; an ancient weapon from Asian peninsula}

\author{
Yogi Meranggi ${ }^{1}$
}

${ }^{1}$ PT. PLN (Persero) Area Bali Timur yogimeranggi@gmail.com

\section{Editor:}

Ida Bagus Ngurah Tri Pramana
Received : 2019-05-25 Accepted : 2019-06-12 Published: 2019-06-30

\title{
ABSTRACT
}

Out of many weapons possessed by myriad inhabitant tribes of southeast Asia, Keris is probably the most unique and well known. The dagger is a common weapon along the Malayan Peninsula, Indonesia, and the Philippines. Keris can be classified into two types based on its shape, namely straight Keris and Luk (wavy) Keris, which always odd in number. Empu, the name given to the Keris maker, hardened iron as the core material in making the knife with particular techniques passed from their predecessor. An object can be classified as a Keris if it has fulfilled the strict prerequisite of
Keris. Today's society put Keris as heritage that should be preserved. Its function progressed from the weapon into antiques, part of the traditional ceremony or even considered as a sacred relic by in Balinese communities. In addition, Keris is also hunted by collectors who put interest on it. The weapon was made throughout a long and challenging process. To keep its durability from the natural oxidation process, therefore, the Keris owner is compulsory to do regular cleaning to preserve its shine and durability.

Keyword: Keris, Weapon, Society

Cite This Article: Meranggi, Y. Introduction of Keris; an ancient weapon from Asian peninsula. Bali Tourism Journal (BTJ)2019, 3 (1): 22 -25

\section{INTRODUCTION}

In ancient Society of Indonesia, weapons play two distinct roles as a tactical weapon and prestigious item. Out of many weapons possessed by myriad inhabitant tribes of southeast Asia, Keris is probably the most unique and well known. The dagger is a common weapon along the Malayan Peninsula, Indonesia, and the Philippines. ${ }^{1,2,3}$ It has a distinct wavy shape on its blade, but there is also a straightshaped keris. Its characteristics and process of making keris vary depend on the culture and the period when it was made. This writing discusses the characteristics and some trivia of this precious antique weapon.

\section{KERIS IN HISTORY OF INDONESIA}

Keris can be classified into two types based on its shape, namely straight Keris and Luk (wavy) Keris, which always odd in number. ${ }^{4}$ The blade is flat and elongated with two sharp edges and pointed tip. A suitable figure as a stabbing weapon. According to History of Java (1817) by Raffles, He mentioned the Keris holds a definite position among the Javanese soldiers. They carried three daggers at a time. On their left waist was Keris from their wedding (Kancing Gelung), On the right waist from their parents, the third Keris is the one they used in battle, however as the last arsenal to end the fight, unlike sword or spear. ${ }^{5}$
In ancient inscriptions, the term of Keris has been discussed such as the one inscribed on a bronze plate in Karangtengah, dated 748 Saka, or 842 AD. The script mentions several types of offerings to determine Poh as a tax-free area; they offered various items like Kres, wangkiul, tewek punukan, and wesi penghatap. Kres is the keris, wangkiul is a spear, whereas tewek punukan is a doubleedged weapon. Another record is the one written by a Chinese traveler in $922 \mathrm{AD}$. On his visit to the Kahuripan kingdom on Brantas Riverbank, East Java, he described 'a short sword with hilts made of rhinoceros horn or gold' was given to Emperor of China as a gift from Javanese Maharaja.?

In the lower corner of southeast relief of Borobudur Temple, in Central Java, Soldiers depicted carrying sharp blade resemblance to Keris. The similar carving also engraved In Prambanan Temple portrayed a giant holding the knife. In Sewu Temple, near Prambanan, A huge statue, slipping a sharp weapon, like a keris on its waist. Among many reliefs in temples throughout Java region, the relief on Sukuh temple probably is the most important finding. The relief displayed fragment about how the keris had been made. It answered the method of making Keris was by folding and forging metals in hot blazing flame. ${ }^{9}$

\section{THE FORGING METHOD}

Empu, the name given to the Keris maker, hardened iron as the core material in making the 


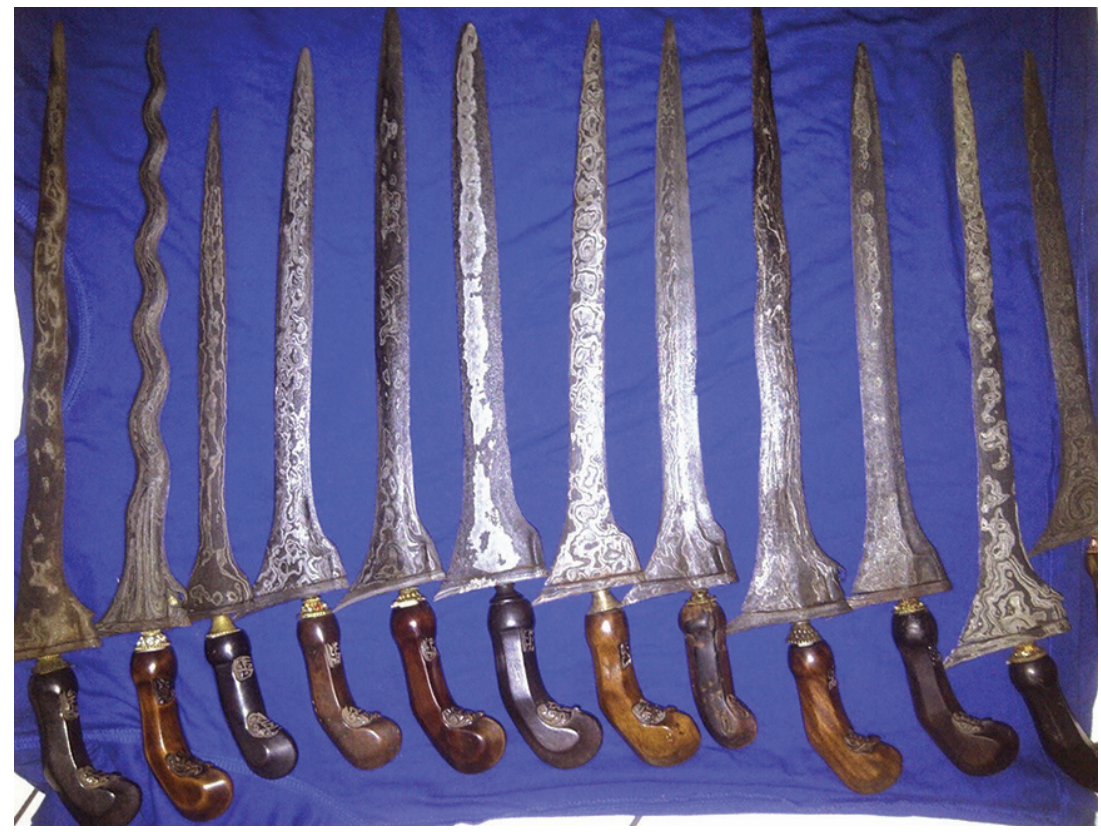

Figure 1. Keris has a distinct wavy shape on its blade, but there is also a straight-shaped keris ${ }^{6}$

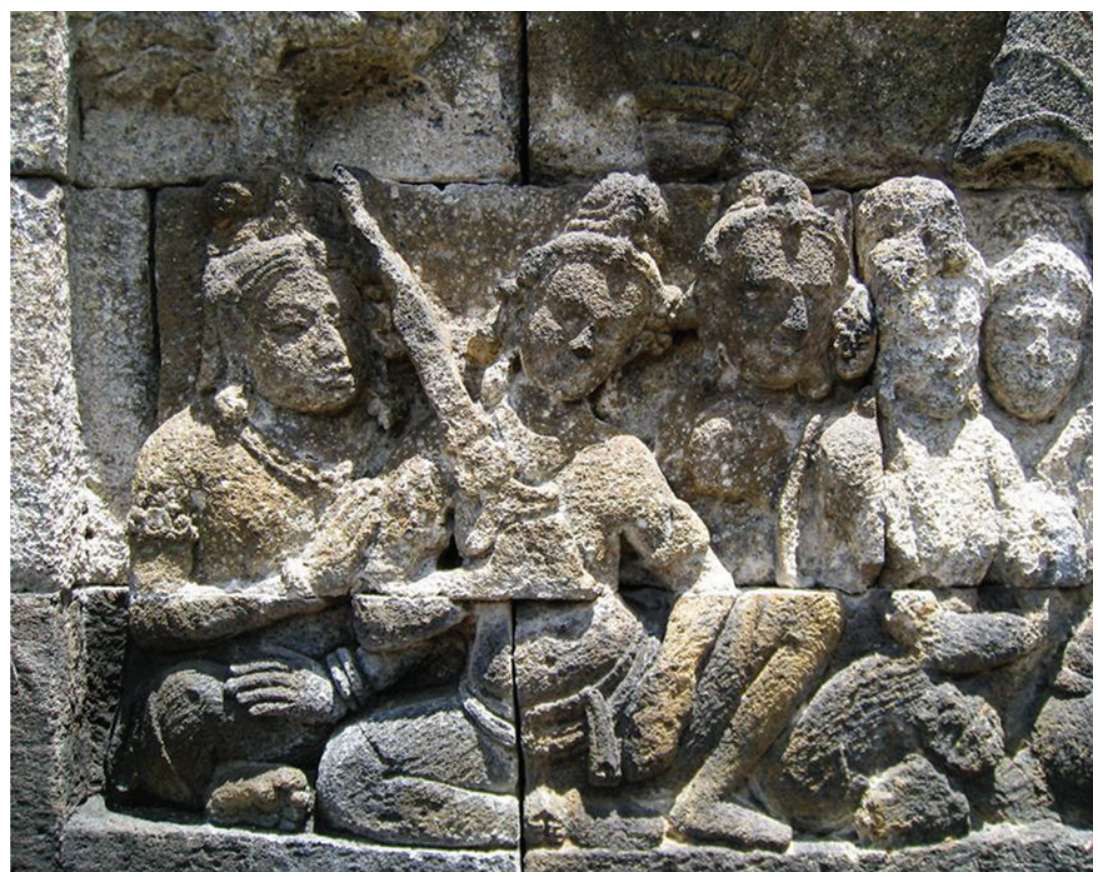

Figure 2. Southeast relief of Borobudur Temple ${ }^{8}$

knife with particular techniques passed from their predecessor. Old fashioned method to improve the metal solidity was by dipping the blazing steel to a particular chemical liquid until it coated thoroughly. However, this practice resulted in a weapon to have a thick outer but remain fragile on the core. Hence, it is preferable to be used as finishing rather than to strengthen the blade. The second technique conducted by inserting different type of metals while folding and forging the dagger. The Empu chose a flexible nature metal, serves as a framework to the Keris; thus, it would be more durable. The results of this process also emerging a silver pattern on the blade that is commonly called pamor. The pamor gives aesthetic value to the dagger. As the science of metallurgy and technology in forging continue to improve, the technique of making weapon as prestigious possession also flourished. The Empu may design the pamor motifs rather than let it formed naturally through the forging process. According to the myth, it is said that every pamor hold its mystical value that gives a particular effect to the owner of the keris. It might bring profits or losses to its master.

This stabbing weapon on its journey becomes a cultural heritage. Its value rests on the various phases that the Empu should pass before the dagger could be given to the requester. It is more likely to be addressed as spiritual work rather than a mere process of forging weaponry. The empu in making a keris could spend monthly to yearly to finish a single blade. The stages start from the process of meditation to determine the suitable day to start the work, including conducting special rituals to imbued a 'soul' to the weapon. Besides, the length of a keris represents its function. By measuring a keris from its base to tip using four fingers, the remaining length of the keris indicated the purpose of the keris. Three fingers mean it is to help the owner in decision-making, two fingers for spiritual purposes, one and a half fingers as an amulet, and last but not least, one finger is believed for agriculture. ${ }^{10}$

\section{AESTHETICAL AND PHILOSOPHICAL VALUE}

An object can be classified as a Keris if it has fulfilled the strict prerequisite of Keris. The reason stands on core principle; thus, it can be distinguished with any other handheld weapon. The dagger must consist of two main parts, namely the blade part (including pesi) and Ganja. The length of the blade is at least $30 \mathrm{~cm}$ and a maximum of $42 \mathrm{~cm}$. The usual length of the keris blade is between $33-38 \mathrm{~cm}$. Some keris outside Java can reach $58 \mathrm{~cm}$. In Bali, the average size is $40-45 \mathrm{~cm} .{ }^{11}$ The blade part represents Lingga, while the ganja symbolizes Yoni. In the Hindu philosophy, the union of lingga and yoni is a symbol of hope for fertility, eternity (preservation), and strength. The blade must always make a certain angle to the ganja, not perpendicular. The sloping or leaning dagger represents a philosophy, whatever his rank and position, must always show respect not only to the creator but also to others. Furthermore, 


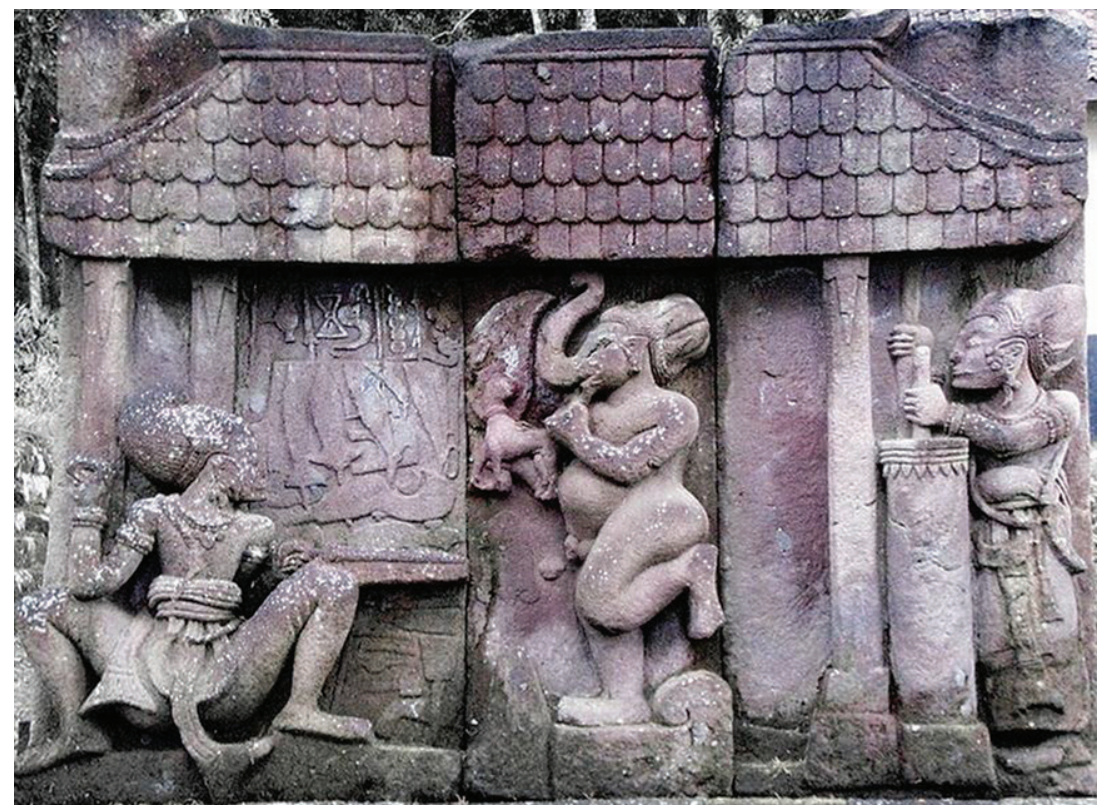

Figure 3. The relief on Sukuh temple ${ }^{8}$
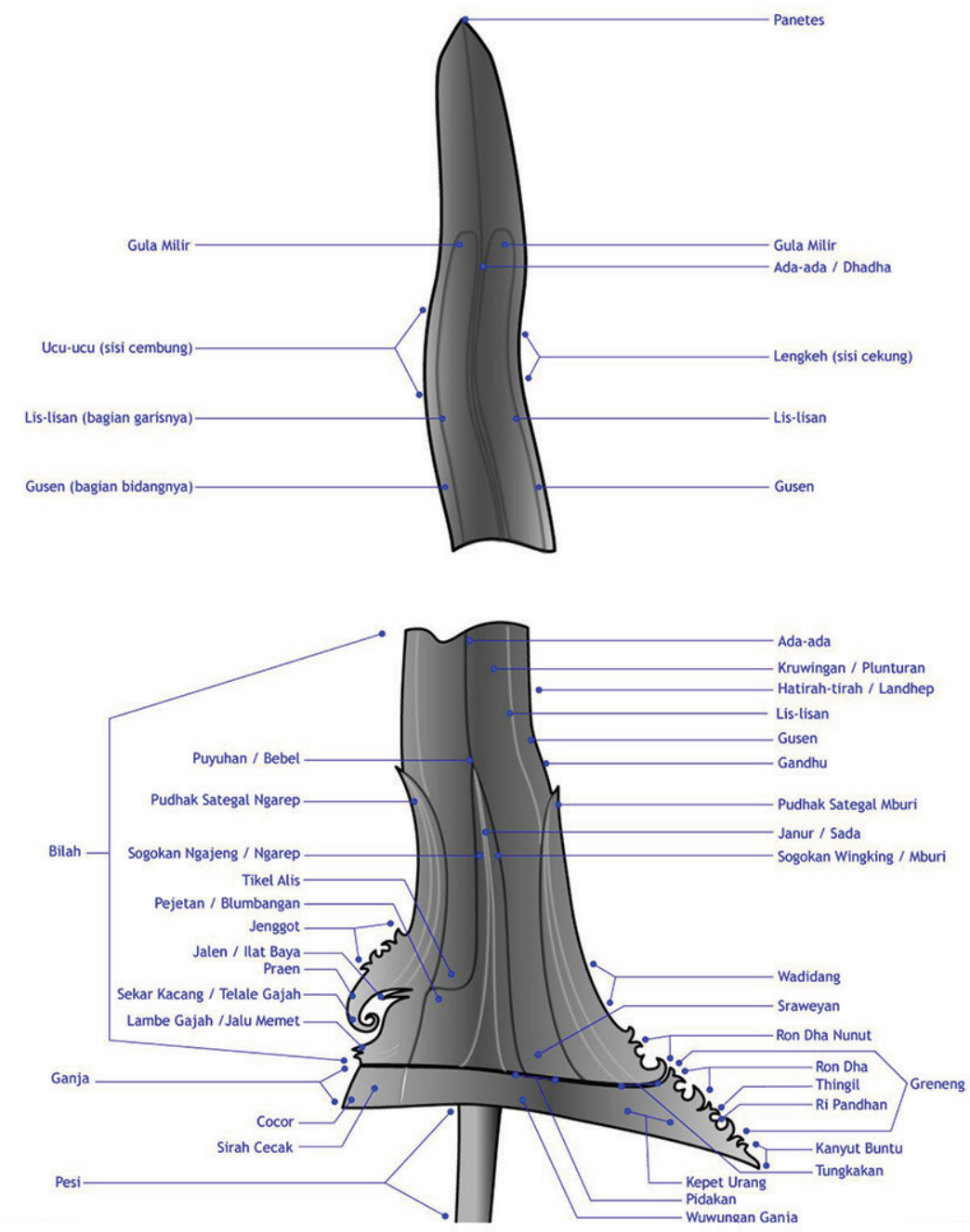

Figure 4. Details of a Keris ${ }^{13}$
Keris has some decorative details called Ricikan. Keris usually forged from three kinds of metal such as iron, steel and prestige material or at least two metals. In previous study analyzing Keris collection at Tosan Aji Purworejo Museum, the results of the analysis using the $\mathrm{x}$-ray method showed that elements that were recognizable in the metal weapons were $\mathrm{Fe}$ (iron), Ni (nickel), Re (Rhenium), $\mathrm{Cu}$ (copper), Sn (Tin), Cr (chromium), Au (Gold), $\mathrm{Mn}$ (manganese), $\mathrm{Zn}$ (zinc), and $\mathrm{Nb}$ (niobium). ${ }^{12}$

Pesi, a cylindrical iron and extends from five to eight $\mathrm{cm}$, inserted to the handle or in local tongue called ukiran. Ganja is a blunt-edged separated base of the blade to protect the hand from the blade base sharp edge. The Ukiran usually made of wood, ivory, or horns. The material is soaked in a mixture of herbs for months before shaped into a handle. Its shape is simple, but for a prestigious one, the ukiran sometimes compounded with gemstone or even covered with gold. In Bali region, the ukiran is carved into a figure of a deity, priest, dancer, giant, horse head, or any figure. The typical form of Balinese style is a giant figure with a radiant face. the handle symbolizes magical power as well as adds intimidating effect to the blade. ${ }^{7}$

\section{KERIS IN MODERN SOCIETY}

Today's society put Keris as heritage that should be preserved. It is no longer serve as a weapon or daily utensil. Its function progressed into antiques or part of a traditional ceremony. Some people keep Keris as a sacred relic in the temple, especially in Balinese communities. In addition, collectors of antique who put interest on it willingly spend their time only to find the best keris. The historical, artistic, as well as its mystical value, invites people around the globe to travel far away and spend their fortune to obtain the blade.

Although the weapon was made throughout a long and challenging process, it remains a metal object that can be damaged due to the natural oxidation process. Therefore, the Keris owner is compulsory to do regular cleaning to maintain its shine and durability. ${ }^{14}$ The keris should be maintained its purity both physically and yet spiritually for the sacred one. The physical maintenance is conducted by annual clean or every six months if necessary. The cleaning process must be done carefully, or it might damage the knife. Commonly, the cleaning process should be applied if it is started to get a rusty stain. The blade is washed by soaking it on the coconut water for several days. Should the stain persistent to be removed, then it is gently scrubbed with lemon juice until the rust dissolves from the blade. The process must be 


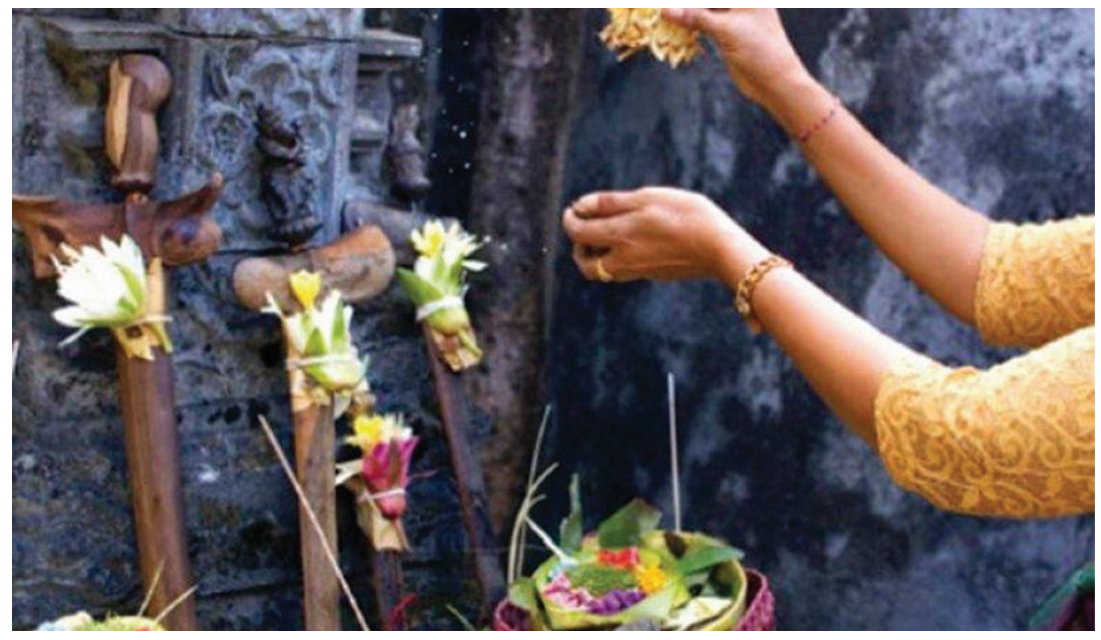

Figure 5. Ritual on Tumpek landep ${ }^{16}$

conducted in a sacred area for the holy Keris. After the cleaning process, the Keris will be coated with coconut oil mixed with fragrance oil. ${ }^{15}$

In Bali, Keris and other weaponry or sharpedged object are cleaned and celebrated by ritual, once every 210 days on Tumpek Landep day. The objects are cleaned, placed in the temple altar, sprinkled with holy water, and presented with offerings. Locals honor the blade with red flowers as an embodiment of Lord Brahma (the God of Fire and creation). The ceremony is also a prayer to Lord Pasupati, asking for a 'sharp mind,' a highly determined will to walk on righteous path. ${ }^{10}$

\section{CONCLUSION}

Based on its shape, Keris can be divided into two types, namely straight Keris and Luk (wavy) Keris. The Empu forge various metals in making the knife with particular techniques passed from their predecessor. The process of making the blade is considered a spiritual work rather than a mere forging process. An object is identified as a Keris if it has fulfilled the strict prerequisite of Keris. Today's society put Keris as heritage that should be preserved. Its function progressed from the weapon into antiques, part of the traditional ceremony or even considered as a sacred relic by in Balinese communities. In addition, Keris is also hunted by collectors who put interest on it. The weapon was made throughout a long and challenging process.
To keep its durability from the natural oxidation process, therefore, the Keris owner is compulsory to do regular cleaning to preserve its shine and durability.

\section{REFERENCES:}

1. Hamzuri. 1988. Keris. Penerbit Djambatan.

2. Huda, Arief Syaifuddin. 2010. Sejarah Keris. Jakarta: DFS Publisher.

3. Moebirman. 1970. Keris and other weapons of Indonesia. Jakarta: Yayasan PelitaWisata.

4. Djomul, Mas. 1985. Keris, benda budaya. Jakarta: Aksara Baru bekerja sama dengan Taman Mini Indonesia Indah.

5. Raffles, Thomas Stamford. The history of Java. Vol. 1. BoDBooks on Demand, 2018.

6. Image from Ki Korowelang keris solo jual beli dan tukar tambah segala keris buatan kuno/antik ,baru dan unik. 2015. Available at URL: http://kikorowelang.blogspot. com/2015/03/beberapa-jenis-dapur-keris.html

7. Endah E. Posisi Keris Pada Masyarakat Jogja Modern. Jurnal Komunikasi, 2016, 7.2: 137-151.

8. Image by Gunawan K. Penggambaran benda mirip keris di Relief - Koleksi Keris jawa. 2010. Available at URL: https:// luk.staff.ugm.ac.id/keris/Jawa/01.html

9. SD Suryono. Pola Pamor Keris Tangguh Surakarta. Ornamen Jurnal Kriya Seni ISI Surakarta, 2016, 2.1.

10. Y Paramartha. Keris Dalam Kebudayaan oleh Neka Art Museum. Pandebaik[dot]com. 2010. Available at URL: http://www.pandebaik.com/2010/07/20/keris-dalamkebudayaan-oleh-neka-art-museum/

11. Aneka Keris Nusantara Dipamerkan di Museum Bali. Kumparan[dot]com. 2018. Available at URL: https:// kumparan.com/kanalbali/aneka-keris-nusantaradipamerkan-di-museum-bali-1539989980197631026

12. RAG Purnawibawa. Analisis Kandungan Unsur dan Tingkat Kekerasan Pada Senjata Logam Koleksi Museum Tosan Aji Purworejo. Jurnal Konservasi Cagar Budaya Borobudur, 2016, 10.2: 31-39.

13. Image taken from URL: https://sites.google.com/site/ seputartosanaji/ricikan-keris

14. D Trinitya. Stigma Klenik pada Keris Pusaka Bikin Keris Kuno Nyaris Punah. Baliexpress[dot]jawapos[dot]com. 2018. Available at URL: https://baliexpress.jawapos.com/ $\mathrm{read} / 2018 / 10 / 25 / 100242 /$ stigma-klenik-pada-kerispusaka-bikin-keris-kuno-nyaris-punah

15. A Bayu. Begini Cara Merawat dan Jaga Taksu Keris. Baliexpress[dot]jawapos[dot]com. 2019. Available at URL: https://baliexpress.jawapos.com/read/2019/02/26/121684/ begini-cara-merawat-dan-jaga-taksu-keris

16. Image taken from PHDI official website. Tumpek Landep. Phdi[dot]or[dot]id. Available at URL: http://phdi.or.id/ artikel/tumpek-landep.

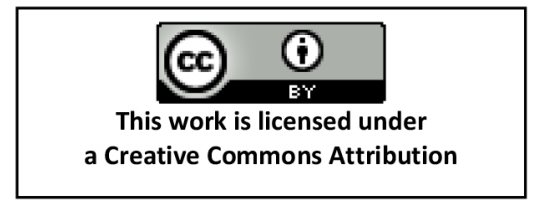

